\title{
Molecular systematics of the Dichopetala genus group (Orthoptera: Phaneropteridae)
}

\author{
Aurora Y. Rocha-Sánchez ${ }^{1}$, Alejandro Zaldívar-Riverón², Vladimir Salvador de Jesús-Bonilla², \\ Ludivina Barrientos-Lozano ${ }^{1 *} \&$ Alfonso Correa-Sandoval $^{1}$ \\ 1. Tecnológico Nacional de México-Instituto Tecnológico de Cd. Victoria. División de Estudios de Posgrado e \\ Investigación. Blvd. Emilio Portes Gil No. 1301. C. P. 87010, Cd. Victoria, Tamaulipas, Mexico; \\ ludivinab@yahoo.com \\ 2. Universidad Nacional Autónoma de México-Instituto de Biología, Departamento de Zoología, 3er Circuito Exterior \\ s/n, Cd. Universitaria, Apartado Postal 70-153, C.P. 04510, CdMx, Mexico. \\ * Correspondence
}

Received 03-II-2019. C Corrected 01-VII-2019. Accepted 27-IX-2019.

\begin{abstract}
Introduction: The Dichopetala genus group was proposed recently after revision of the genus Dichopetala Brunner von Wattenwyl, 1878. Currently, the group consists of eight genera and 44 species distributed from Southern United States to Southern Mexico. This generic arrangement was based solely on morphological evidence, and was accompanied by discussions on new erected genera, for which their monophyly was not tested. Objective: To assess the phylogenetic relationships among representative species of the eight genera of the Dichopetala group. Methods: We generated DNA sequences for one mitochondrial (Cytochrome oxidase I: COI) and two nuclear (28S, Histone III: H3) gene markers, and included species of other Phaneropterinae genera to test the monophyly of the ingroup; Bayesian and maximum likelihood evolutionary models were used. Results: The monophyly of the Dichopetala group and the monophyly of genera Dichopetala, Obolopteryx, Planipollex, Mactruchus and Rhabdocerca is supported. In addition, Acanthorintes and Pterodichopetala were recovered as paraphyletic. The mitochondrial markers also suggest that the widely distributed genera Rhabdocerca and Acanthorintes may actually contain various overlooked species. Conclusions: The first contribution on the Phylogeny of the Dichopetala group, and a more robust phylogenetic and morphological definition of some of the genera involved are provided.
\end{abstract}

Key words: Dichopetaline genera, molecular analyses, monophyly, morphology.

Rocha-Sánchez, A. Y., Zaldívar-Riverón, A., de Jesús-Bonilla, V. S., Barrientos-Lozano, L., \& Correa-Sandoval, A. (2019). Molecular systematics of the Dichopetala genus group (Orthoptera: Phaneropteridae). Revista de Biología Tropical, 67(6), 1431-1448.

The subfamily Phaneropterinae (Orthoptera: Tettigonioidea) was described by Burmeister (1838); currently, it comprises 33 tribes and c.315 genera distributed worldwide (Cigliano, Braun, Eades, \& Otte, 2018). Among Tettigonioidea, Phaneropterinae is perhaps the subfamily with the highest abundance and species richness in Mexico, with records for the country ranging from 156 to 163 species
(Barrientos-Lozano, 2004; Fontana, Buzzetti, \& Mariño-Pérez, 2008; Barrientos-Lozano, Rocha-Sánchez, Buzzetti, Méndez-Gómez, \& Horta-Vega, 2013b). For more than a century, classification of Phaneropterinae relied exclusively on morphological features (Brunner von Wattenwyl, 1878; Rehn \& Hebard, 1914; Cohn, Swanson, \& Fontana, 2014). However, as in other orthopteran taxa (e.g. De Jesús-Bonilla, 
Barrientos-Lozano, \& Zaldívar-Riverón, 2017; Sanabria-Urbán, Song, Oyama, González-Rodríguez, \& Cueva Del Castillo, 2017), species delimitation and recognition of supraspecific groups in this subfamily have been considerably problematic. The latter due to the existence of species complexes in an apparent initial state of differentiation, and the recent discovery of several new species and genera for the subfamily (Arce-Pérez \& Morón, 2000; Walker, Forrest, \& Spooner, 2003; Rocha-Sánchez, Barrientos-Lozano, Zaldívar-Riverón, \& Almaguer-Sierra, 2016; Heller et al., 2017).

Dichopetala Brunner von Wattenwyl, 1878 is a genus of Phaneropterinae that was largely neglected in taxonomic studies. Until few years ago, it comprised 19 described species but only six were closely related according to morphological evidence (Cohn et al., 2014). Recently, Cohn et al. (2014), carried out a taxonomic revision for members of the genus Dichopetala, confirming the presence of various morphologically distinct groups. The authors pointed out that "if all the Dichopetala species were included in that genus, there would only be a single diagnostic character, the females' subgenital plate". They also indicated that male genital structures (e.g., cerci, supranal plate, epiproct, phallic complex, and subgenital plate) exhibited extensive variation, and thus they could not be used to define the genus. Based on this, the above authors proposed the Dichopetala genus group (temporary name), to include two previously recognized genera, Dichopetala and Pterodichopetala, plus six new erected genera: Obolopteryx, Planipollex, Rhabdocerca, Gymnocerca, Mactruchus, and Acanthorintes (Cohn et al., 2014) (Table 1). Currently, the Dichopetala group includes eight genera and 44 species (Cigliano et al., 2018).

The use of molecular markers, both nuclear and mitochondrial, have shed light on the phylogenetic relationships of a large number of insect groups at different taxonomic levels, including orthopterans (e.g. Mugleston, Song, \& Whiting, 2013; Song, 2015; De JesúsBonilla et al., 2017; Kensinger, Schwemm, \& Luttberg, 2017; Sanabria-Urbán et al., 2017;
Grzywacz, Lehmann, Chobanov, \& Lehmann, 2018). In this study we aimed to investigate the phylogenetic relationships among species of the eight representative genera that belong to the Dichopetala group to test both the monophyly of the group as well as of its genera. We generated sequences of one mitochondrial (Cytochrome oxidase I: COI) and two nuclear (28S, Histone III: H3) markers. We also included representative specimens from various populations of some species with wide geographic distribution in order to explore whether they actually represent composite taxa.

\section{MATERIALS AND METHODS}

Examined material: Specimens of the Dichopetala group and other Phaneropterinae were collected in different localities along the Mexican territory from 2000 to 2018 (Table 2). Determination to species level was carried out using relevant literature and resources online (Fontana et al., 2008; Barrientos-Lozano, Ramírez-Núñez, Rocha-Sánchez, Horta-Vega, \& Almaguer-Sierra, 2013a; Barrientos-Lozano et al., 2013b; Cohn et al., 2014; Cigliano et al., 2018). We generated sequences for 60 specimens of the Dichopetala group. These specimens were assigned to 25 taxa out of the 44 currently described species. The remaining sequences belong to 35 morphospecies that could not be assigned to any of the described species. These morphospecies correspond to the genera that have the widest geographic distribution (Acanthorintes, Obolopteryx, Planipollex, Pterodichopetala and Rhabdocerca).

We also included 36 specimens belonging to ten additional genera of Phaneropterinae to test the monophyly of the Dichopetala group (Table 2). These genera are as follows: Amblycorypha Stål, 1873, Stilpnochlora Stål, 1873, Philophyllia Stål, 1873, Petaloptera Saussure, 1859, Microcentrum Scudder, 1862, Pycnopalpa Serville, 1838, Turpiliodes Hebard, 1932, Scudderia Stål, 1873, Insara Walker, 1869 and Vellea Walker, 1869. Published Sequences of Conocephalus sp., of the Conocephalinae subfamily, were used to root 
TABLE 1

Taxonomic organization of the Dichopetala group

Genus Species

Acanthorintes Cohn, Swanson and Fontana, 2014 A. erythrephaptor Cohn, Swanson and Fontana, 2014

A. neomexicanus (Barrientos-Lozano and Ramírez-Núñez, 2013)

A. tauriformis (Rehn and Hebard, 1914)

A. thenarocercus Cohn, Swanson and Fontana, 2014

A. xanthephaptor Cohn, Swanson and Fontana, 2014

A. zeuglaius Cohn, Swanson and Fontana, 2014

Dichopetala Brunner von Wattenwyl, 1878

D. mexicana Brunner von Wattenwyl, 1878

Gymnocerca Cohn, Swanson and Fontana, 2014 G. cycloprista Cohn, Swanson and Fontana, 2014

G. enaulites Cohn, Swanson and Fontana, 2014

G. falcata (Rehn and Hebard, 1914)

Mactruchus Cohn, Swanson and Fontana, 2014

M. cryothermastris Cohn, Swanson and Fontana, 2014

M. durangensis (Rehn and Hebard, 1914)

M. ischnodus Cohn, Swanson and Fontana, 2014

M. megasynactor Cohn, Swanson and Fontana, 2014

M. serrifer (Rehn and Hebard, 1914)

Obolopteryx Cohn, Swanson and Fontana, 2014

O. brevihastata (Morse, 1902)

O. castanea (Rehn and Hebard, 1914)

O. catinata (Rehn and Hebard, 1914)

O. emarginata (Brunner von Wattenwyl, 1878)

O. eurycerca Barrientos-Lozano and Rocha-Sánchez, 2016

O. gladiator (Rehn and Hebard, 1914)

O. huastecana Barrientos-Lozano and Rocha-Sánchez, 2016

O. nigra Barrientos-Lozano and Rocha-Sánchez, 2016

O. oreoeca (Rehn and Hebard, 1914)

O. poecila (Hebard, 1932)

O. seeversi (Strohecker, 1941)

O. tamaholipana Barrientos-Lozano and Rocha-Sánchez, 2016

O. tanchipae Barrientos-Lozano and Rocha-Sánchez, 2016

O. truncoangulata Barrientos-Lozano and Rocha-Sánchez, 2015

Planipollex Cohn, Swanson and Fontana, 2014

P. pollicifer (Rehn and Hebard, 1914)

Pterodichopetala Buzzetti, Barrientos-Lozano

P. alfredoi Barrientos-Lozano and Rocha-Sánchez, 2013

and Rocha-Sánchez, 2010

P. cieloi Buzzetti, Barrientos-Lozano and Rocha-Sánchez, 2010

P. cultricerca (Strohecker, 1945)

P. geovanyi Barrientos-Lozano and Rocha-Sánchez, 2015

P. hypsibates Cohn, Swanson and Fontana, 2014

P. monternach Barrientos-Lozano and Zaldívar-Riverón, 2015

P. padrisima Cohn, Swanson and Fontana, 2014

P. pityophila Cohn, Swanson and Fontana, 2014

P. robertoi Barrientos-Lozano and Rocha-Sánchez, 2015

P. strepsidactyla Cohn, Swanson and Fontana, 2014

P. tuliensis Barrientos-Lozano and Rocha-Sánchez, 2015

Rhabdocerca Cohn, Swanson and Fontana, 2014 R. caudelli (Rehn and Hebard, 1914)

R. tridactyla (Rehn and Hebard, 1914)

R. zanclophora Cohn, Swanson and Fontana, 2014

Cohn et al., 2014. 
TABLE 2

Taxa of the Dichopetala group and other genera of Phaneropterinae included in the phylogenetic analyses

\begin{tabular}{|c|c|c|c|c|c|}
\hline Tribe & Group & Genus & species & Collection locality & Voucher \\
\hline \multirow[t]{47}{*}{ Odonturini } & Dichopetala & Acanthorintes & xanthephaptor & San José de Iturbide, Guanajuato & P006 \\
\hline & & & zeuglaius & Tula, Tamaulipas & P013 \\
\hline & & & sp. 1 & San José de Iturbide, Guanajuato & P030 \\
\hline & & & sp. 2 & Guadalcazar, San Luis Potosí & P050 \\
\hline & & & sp. 3 & Apaseo el Alto, Guanajuato & P051 \\
\hline & & & sp. 4 & Querétaro, Querétaro & P061 \\
\hline & & & sp. 5 & Guadalcazar, San Luis Potosí & P062 \\
\hline & & & sp. 6 & Polotitlán, Estado de México & P064 \\
\hline & & & sp. 7 & El Marques, Querétaro & P065 \\
\hline & & & neomexicanus & Soto La Marina, Tamaulipas & P208 \\
\hline & & Dichopetala & mexicana & Teloloapan, Guerrero & P004 \\
\hline & & & mexicana & Tepexi de Rodríguez, Puebla & P049 \\
\hline & & Gymnocerca & enaulites & Mártir de Cuilapan, Guerrero & P007 \\
\hline & & Mactruchus & serrifer & Jalisco, Guadalajara & P008 \\
\hline & & & serrifer & Ixtlán del Rio, Nayarit & P066 \\
\hline & & Obolopteryx & castanea & Hidalgo, Tamaulipas & P001 \\
\hline & & & truncoangulata & Palmillas, Tamaulipas & P002 \\
\hline & & & nigra & Tula, Tamaulipas & P026 \\
\hline & & & poecila & Tula, Tamaulipas & P027 \\
\hline & & & sp. 1 & Victoria, Tamaulipas & P079 \\
\hline & & & sp. 2 & Victoria, Tamaulipas & P080 \\
\hline & & & sp. 3 & Mante, Tamaulipas & P081 \\
\hline & & & sp. 4 & Valles, San Luis Potosí & P082 \\
\hline & & & eurycerca & Hidalgo, Tamaulipas & P173 \\
\hline & & Planipollex & chirura* & Antiguo Morelos, Tamaulipas & P012 \\
\hline & & & pollicifer & Gómez Farías, Tamaulipas & P003 \\
\hline & & & sp. 1 & Huejutla de Reyes, Hidalgo & P029 \\
\hline & & & sp. 2 & Naranjos Amatlán, Veracruz & P202 \\
\hline & & Pterodichopeta & acieloi & Gómez Farías, Tamaulipas & P016 \\
\hline & & & hypsibates & Galeana, Nuevo León & P023 \\
\hline & & & monternach & Guadalcazar, San Luis Potosí & P020 \\
\hline & & & padrisima & Arteaga, Coahuila & P195 \\
\hline & & & robertoi & Galeana, Nuevo León & P186 \\
\hline & & & robertoi & Galeana, Nuevo León & P188 \\
\hline & & & tuliensis & Tula, Tamaulipas & P018 \\
\hline & & & sp. 1 & Galeana, Nuevo León & P025 \\
\hline & & Rhabdocerca & caudelli & Tula, Tamaulipas & P009 \\
\hline & & & zanclophora & Guadalcazar, San Luis Potosí & P043 \\
\hline & & & sp. 1 & Concepción del Oro, Zacatecas & P010 \\
\hline & & & sp. 2 & Arteaga, Coahuila & P031 \\
\hline & & & sp. 3 & San Pedro, Nuevo León & P032 \\
\hline & & & sp. 4 & Santiago, Nuevo León & P033 \\
\hline & & & sp. 5 & San Luis Potosí, San Luis Potosí & P036 \\
\hline & & & sp. 6 & Cedral, San Luis Potosí & P037 \\
\hline & & & sp. 7 & Victoria, Tamaulipas & P039 \\
\hline & & & sp. 8 & Arteaga, Coahuila & P041 \\
\hline & & & sp. 9 & Cerritos, San Luis Potosí & P042 \\
\hline
\end{tabular}




\begin{tabular}{|c|c|c|c|c|c|}
\hline Tribe & Group & Genus & species & Collection locality & Voucher \\
\hline & & & sp. 10 & Iturbide, Nuevo León & P045 \\
\hline & & & sp. 11 & Santiago, Nuevo León & P057 \\
\hline & & & sp. 12 & Palmillas, Tamaulipas & P058 \\
\hline & & & sp. 13 & Cerritos, San Luis Potosí & P059 \\
\hline & & & sp. 14 & Galeana, Nuevo León & P060 \\
\hline & & & sp. 15 & Galeana, Nuevo León & P068 \\
\hline & & & sp. 16 & Iturbide, Nuevo León & P174 \\
\hline & & & sp. 17 & Iturbide, Nuevo León & P176 \\
\hline & & & sp. 18 & Iturbide, Nuevo León & P177 \\
\hline & & & sp. 19 & Iturbide, Nuevo León & P178 \\
\hline & & & sp. 20 & Galeana, Nuevo León & P182 \\
\hline \multirow[t]{7}{*}{ Amblycoryphini } & & Amblycorypha & sp. 4 & Guadalcazar, San Luis Potosí & P111 \\
\hline & & & sp. 5 & Victoria, Tamaulipas & P114 \\
\hline & & & sp. 6 & Ocampo, Tamaulipas & P115 \\
\hline & & & sp. 8 & Ocampo, Tamaulipas & P110 \\
\hline & & & sp. 10 & Huejutla de Reyes, Hidalgo & P098 \\
\hline & & & sp. 11 & Gómez Farías, Tamaulipas & P099 \\
\hline & & & sp. 12 & Gómez Farías, Tamaulipas & P100 \\
\hline \multirow[t]{4}{*}{ Insarini } & & Insara & abbreviata & Teloloapan, Guerrero & P053 \\
\hline & & & covilleae & Cedral, San Luis Potosí & P076 \\
\hline & & & prasina & Jalisco, Guadalajara & P094 \\
\hline & & & tolteca & Xilitla, San Luis Potosí & P075 \\
\hline \multirow{11}{*}{\multicolumn{2}{|c|}{ Microcentrini }} & Microcentrum & rhombifolium & Gómez Farías, Tamaulipas & P117 \\
\hline & & & rhombifolium & San Felipe Orizatlán, Hidalgo & P198 \\
\hline & & & stylatum & Jalisco, Guadalajara & P093 \\
\hline & & & stylatum & Huejutla de Reyes, Hidalgo & P197 \\
\hline & & & syntechnoides & Gómez Farías, Tamaulipas & P073 \\
\hline & & & syntechnoides & Gómez Farías, Tamaulipas & P116 \\
\hline & & & syntechnoides & Gómez Farías, Tamaulipas & P168 \\
\hline & & & sp. 1 & Jalisco, Guadalajara & P086 \\
\hline & & & sp. 2 & Guadalcazar, San Luis Potosí & P118 \\
\hline & & Petaloptera & zendala & Gómez Farías, Tamaulipas & P105 \\
\hline & & Philophyllia & guttulata & Gómez Farías, Tamaulipas & P104 \\
\hline Pycnopalpini & & Pycnopalpa (P.) & bicordata & San Andrés Tuxtla, Veracruz & P055 \\
\hline \multirow[t]{8}{*}{ Scudderiini } & & Scudderia & fasciata & Antiguo Morelos, Tamaulipas & P121 \\
\hline & & & furcata furcata & Galeana, Nuevo León & P184 \\
\hline & & & furcata furcifera & Jalisco, Guadalajara & P088 \\
\hline & & & mexicana & Hidalgo, Tamaulipas & P170 \\
\hline & & & sp. 1 & San Luis Potosí & P120 \\
\hline & & & sp. 2 & Gómez Farías, Tamaulipas & P122 \\
\hline & & & sp. 3 & Victoria, Tamaulipas & P119 \\
\hline & & Vellea & mexicana & San Felipe Orizatlán, Hidalgo & P200 \\
\hline \multirow[t]{6}{*}{ Steirodontini } & & Stilpnochlora & azteca & Arroyo Seco, Querétaro & P194 \\
\hline & & & quadrata & Gómez Farías, Tamaulipas & P106 \\
\hline & & & thoracica & Huejutla de Reyes, Hidalgo & P107 \\
\hline & & & sp. 1 & Gómez Farías, Tamaulipas & P103 \\
\hline & & & sp. 2 & Gómez Farías, Tamaulipas & P169 \\
\hline & Turpiliae & Turpiliodes & mexicanum & San Felipe Orizatlán, Hidalgo & P199 \\
\hline
\end{tabular}

\footnotetext{
*Species under discussion.
} 
the trees (28S: KX429798, H3: KX429889, COI: HQ609222). This subfamily has been recovered as sister to Phaneropterinae (Mugleston et al., 2016).

The examined material is deposited in the Orthoptera collection of the Tecnológico Nacional de México, Instituto Tecnológico de Ciudad Victoria (TecNM-ITCV) and the Colección Nacional de Insectos (CNIN), Instituto de Biología, Universidad Nacional Autónoma de México (IB-UNAM). Specimens were photographed in the field and in the laboratory to confirm their identification. Diagnostic characters taken into account to assign specimens to the different taxa are as follows: in both males and females, shape and size of fastigium of vertex and fastigium frontalis, pronotum dorsal and lateral view; in males, the stridulatory file, cerci in dorsal and ventral view, subgenital plate, and internal genitalia (titillators and phallic complex); in females, subgenital plate, ovipositor and the ovipositor's lobe (Buzzetti, Barrientos-Lozano, \& Rocha-Sánchez, 2010; Barrientos-Lozano et al., 2013a; BarrientosLozano \& Rocha-Sánchez, 2013; Cohn et al., 2014; Barrientos-Lozano, Rocha-Sánchez, \& Correa-Sandoval, 2015; Rocha-Sánchez, Barrientos-Lozano, \& Zaldívar-Riverón, 2015; Barrientos-Lozano, Rocha-Sánchez, ZaldívarRiverón, \& Correa-Sandoval, 2016; Cigliano et al., 2018). Photographs taken in the field were made using a professional camera Nikon D3000. Photographs of diagnostic characters were taken in the laboratory with a MOTIC stereomicroscope SMZ-168 equipped with a 10 $\mathrm{mp}$ digital camera.

Laboratory protocol: Genomic DNA was extracted for each specimen from muscle tissue of the hind leg. DNA was extracted with Chelex (Chelex ${ }^{\circledR}-100$ Bio-Rad) following the protocol mentioned in Zaldívar-Riverón et al. (2006). We also used the DNeasy Bloody Tissue kit (QIAGEN $®$ : Austin, USA) to extract DNA from dry specimens following the protocol mentioned by the manufacturer. Genomic DNA was preserved at $-4{ }^{\circ} \mathrm{C}$ until it was employed for amplification.
We sequenced two nuclear markers: 330 bp of the protein coding $\mathrm{H} 3$ and $725 \mathrm{bp}$ of the ribosomal 28S DNA genes. We also obtained $384 \mathrm{bp}$ of the mitochondrial cytochrome oxidase I (COI) DNA gene. The primers employed to amplify the above gene fragments were: H3: H3F (5'-ATGGCTCGTACCAAGCAGACVGC-3') and H3R (5'-ATATCCTTRGGCATRATRGTGAC-3') (Colgan et al., 1998); 28S: 28SFwd (5'-GCGAACAAGTAACCGTGAGGG-3') (Belshaw \& Quicke, 1997) and 28SRev (5'-GGAGTGCGGAGGCCGCCGCCCMC-3') (De Jesús-Bonilla et al., 2017); COI: LCO (5'-GTCAACAAATCATAAAGATATTGG-3') and HCO (5'-TAAACTTCAGGGTGACCAAAAAATCA-3') (Folmer, Black, Hoeh, Lutz, \& Vrijenhoek, 1994).

Amplification of the selected markers was carried out using the programs described in previous studies (H3: Colgan et al., 1998; 28S: Whiting, 2002; COI: Svenson \& Whiting, 2004). PCRs were carried out in $15 \mu \mathrm{L}$ of total volume containing 10x PCR Buffer (1.5 $\mu \mathrm{L}), \operatorname{MgCl} 2(0.75 \mu \mathrm{L})$, deoxyribonucleotides (dNTP) $(0.3 \mu \mathrm{L})$, primers $(10 \mu \mathrm{M})(0.24 \mu \mathrm{L}$ each), Taq DNA polymerase (Bioline) $(0.12$ $\mu \mathrm{L}), 1 \mu \mathrm{L}$ of DNA and ddH2O (10.85 $\mu \mathrm{L})$. PCR products were sequenced at the Genomic Sequencing Laboratory of Biodiversity and Health of the IB-UNAM. Sequences were edited with Sequencher 4.1.4 (Genecodes Corporation, 2011). The $\mathrm{COI}$ and $\mathrm{H} 3$ alignment were carried out manually with the program PAUP* (Swofford, 2002) and inspected translating them to amino acids with the program Mesquite version 2.75 (Maddison \& Maddison, 2011). The $28 \mathrm{~S}$ marker was aligned manually.

Phylogenetic analyses: Bayesian and maximum likelihood (ML) phylogenetic analyses were performed with the programs MrBayes version 3.2.6 (Ronquist \& Huelsenbeck, 2003) and RAxMLversion 8 (Stamatakis, 2014). Thirty-four specimens could not be sequenced for COI. We therefore analyzed the following two concatenated matrices: (i) $28 \mathrm{~S}+\mathrm{H} 3$, with 94 terminal taxa (CONC94); and (ii) $28 \mathrm{~S}+\mathrm{H} 3$ + COI, with 60 terminal taxa (CONC60). One 
partition was considered for $28 \mathrm{~S}$ and three for each coding protein genes according to their codon positions. The following models were selected for each partition with the program Partition Finder version 2.1.1 (Lanfear et al., 2012): 28S, GTR + G; H3 post1, GTR + I; H3 post2, JC + I; H3 post3, GTR + I + G; COI_post1, GTR + I + G; COI_post2, SYM + G; COI_post3, F81 + I.

The Bayesian analyses had two simultaneous runs and were carried out for 50 million generations each, using four independent Markov Chains, sampling trees every 1000 generations and with a burnin of 0.25 . The resulting trees were used to build a phylogram with posterior probabilities of clades, considering the clades as significantly supported if they had a posterior probability (PP) value 0.95 (e. g. De Jesús-Bonilla et al., 2017). For the ML method, the best tree and its associated bootstrap values were carried out simultaneously. The bootstrap support values were calculated from 1000 replicates, with the estimation of the fixed rate model, using the GTRGAMMA model and random trees as seed. Clades were considered as significantly supported if they had a Bootstrap value (BTP) $\geq 70$ (Hillis \& Bull, 1993).

\section{RESULTS}

Phylogenetic relationships: The Bayesian and ML phylograms recovered similar topologies (Fig. 1, Fig. 2). The topologies derived from all analyses recovered two major clades, one with all members of the Dichopetala group with strong support $(\mathrm{PP}=1.0, \mathrm{BTP}$ =84-85); the second containing the remaining Phaneropterinae genera $(\mathrm{PP}=0.7-1, \mathrm{BTP}=$ 43-56) (Fig. 3, Fig. 4), which was significantly supported by the Bayesian analyses but had a low BTP value.

The Bayesian and ML phylograms derived from the CONC60 matrix recovered the highest number of significantly supported clades (36 and 25 nodes with PP and BTP $\geq 0.95$ and 70, respectively). The Bayesian and ML phylogram obtained with the CONC94 matrix had on the other hand 26 and 19 significantly supported clades (PP $\geq 0.95, \mathrm{BTP} \geq 70)$. In this phylogram, Dichopetala, Obolopteryx, Planipollex and Mactruchus were recovered as monophyletic in the latter two analyses ( $\mathrm{PP} \geq 0.90$, $\mathrm{BTP}=62-91)$. Obolopteryx was recovered as sister to Planipollex $(\mathrm{PP}=0.99, \mathrm{BTP}=48$ ). Mactruchus appeared as sister to Obolopteryx and Planipollex, though with low support (PP $=0.35, \mathrm{BTP}=12)$. . pollicifer and $P$. chirura, appeared nested in two different clades though they are apparently morphologically similar. Nonetheless, cerci, subgenital plate, supranal plate and stridulatory file show consistent inter-specific differences (Fig. 5, Fig. 6). Pterodichopetala was not recovered as monophyletic in this analysis with the CONC94 matrix, since two of its species appeared nested as sister to the remaining members of the Dichopetala group, though the relationships involved were weakly supported.

The Bayesian and ML phylograms with both data sets recovered Acanthorintes as paraphyletic, by having $A$. neomexicanus (CONC60) and A. xanthephaptor (CONC60 and $\mathrm{CONC94)}$ nested separately. Rhabdocerca was recovered as monophyletic in the Bayesian and ML phylogram with the CONC60 matrix $(\mathrm{PP}=0.92, \mathrm{BTP}=1)$, with its taxa being divided into three subclades. The first incorporates $R$. caudelli, $R$. sp. $9, R$. sp. 13 and $R$. zanclophora, which are distributed in the Central Mexican Plateau $(\mathrm{PP}=1, \mathrm{BTP}=71)$. The second accommodates species that occur in the Mexican Altiplano and the eastern portion of the Sierra Madre Oriental (SMO) (Rhabdocerca spp. 5, 7, $6,15$ and $14, \mathrm{PP}=1, \mathrm{BTP}=61)$. The third subclade encompasses species from the northern most portion of the SMO (R. sp. 16, Rhabdocerca spp. 19 and 18, Rhabdocerca spp. 17 and $10, \mathrm{PP}=1, \mathrm{BTP}=99$ ) (Fig. 7). In the Bayesian and ML phylogram with the CONC94 matrix $(\mathrm{PP}=0.40, \mathrm{BTP}=21)$, Rhabdocerca was recovered as paraphyletic, with $A$. neomexicanus deeply nested into this clade.

All phylograms recovered a clade with seven morphospecies originally assigned to Acanthorintes. The latter represents various 


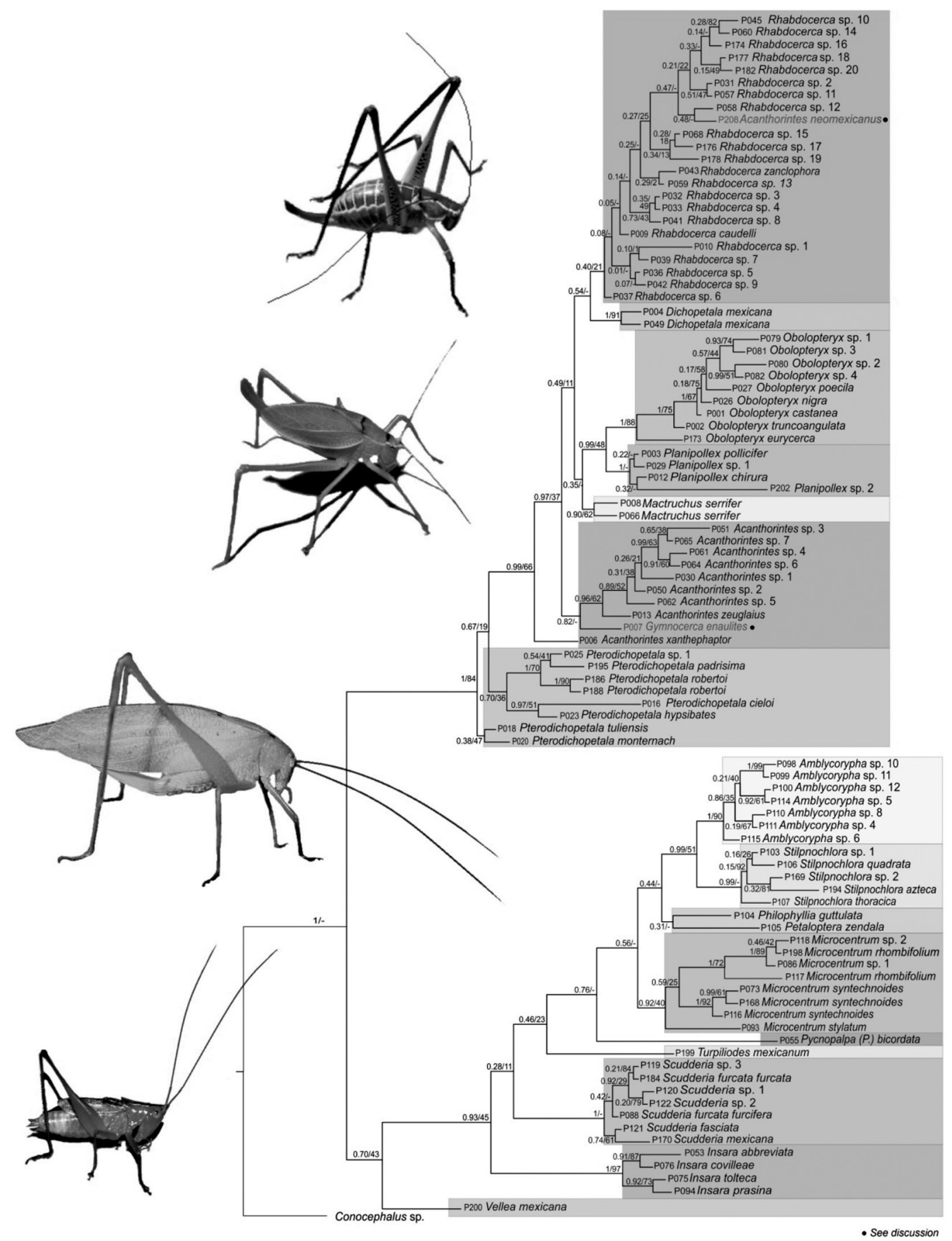

Fig. 1. Bayesian phylogram derived from the CONC94 matrix. The two values on each branch represent Bayesian posterior probability / ML bootstrap values, respectively. Species name in red indicates that its position in the clade does not agree with what is reported taxonomically. 


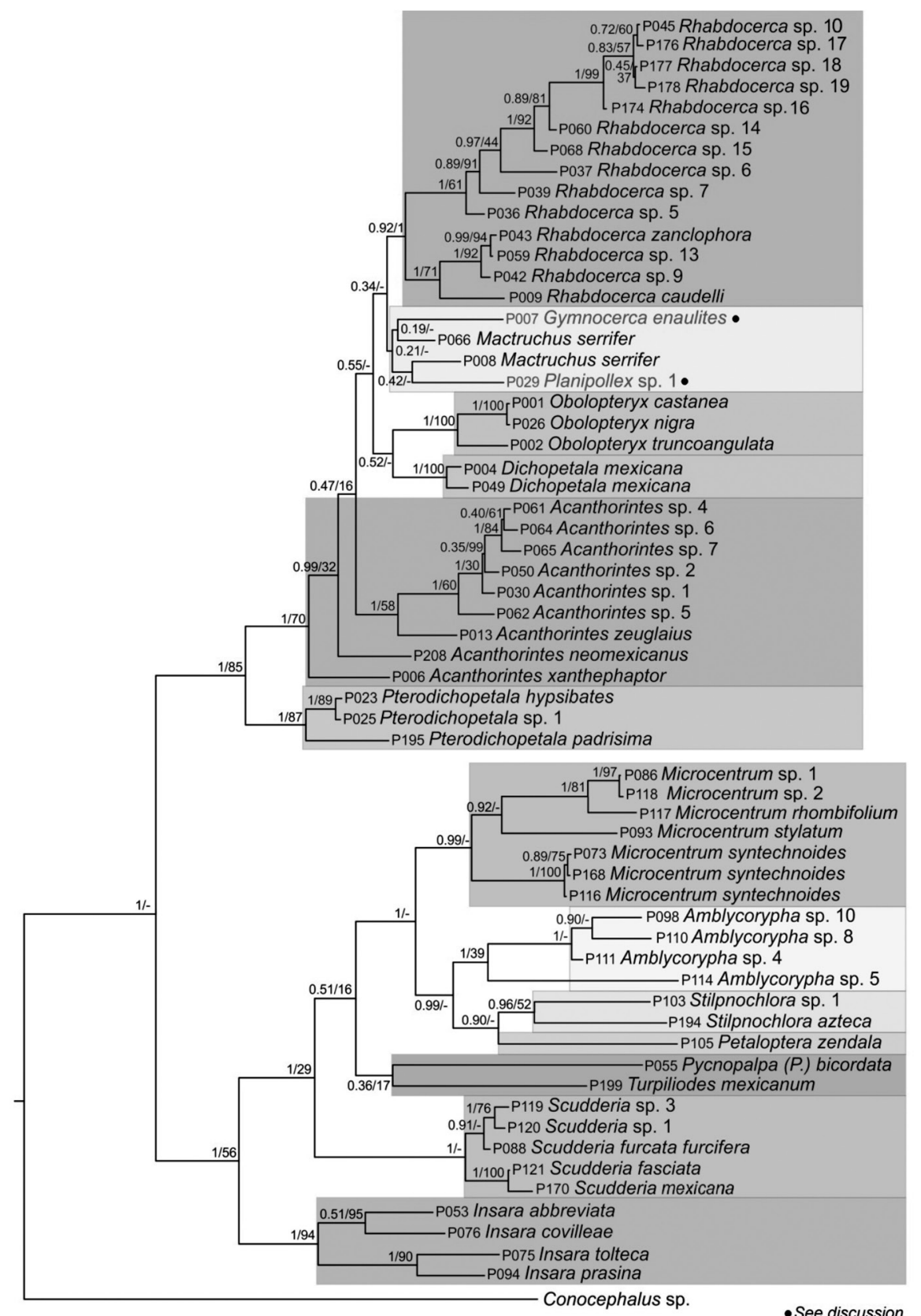

Fig. 2. Bayesian phylogram derived from the CONC60 matrix. The two values on each branch represent Bayesian posterior probability / ML bootstrap values. Species name in red indicates that its position in the clade does not agree with what is reported taxonomically. 

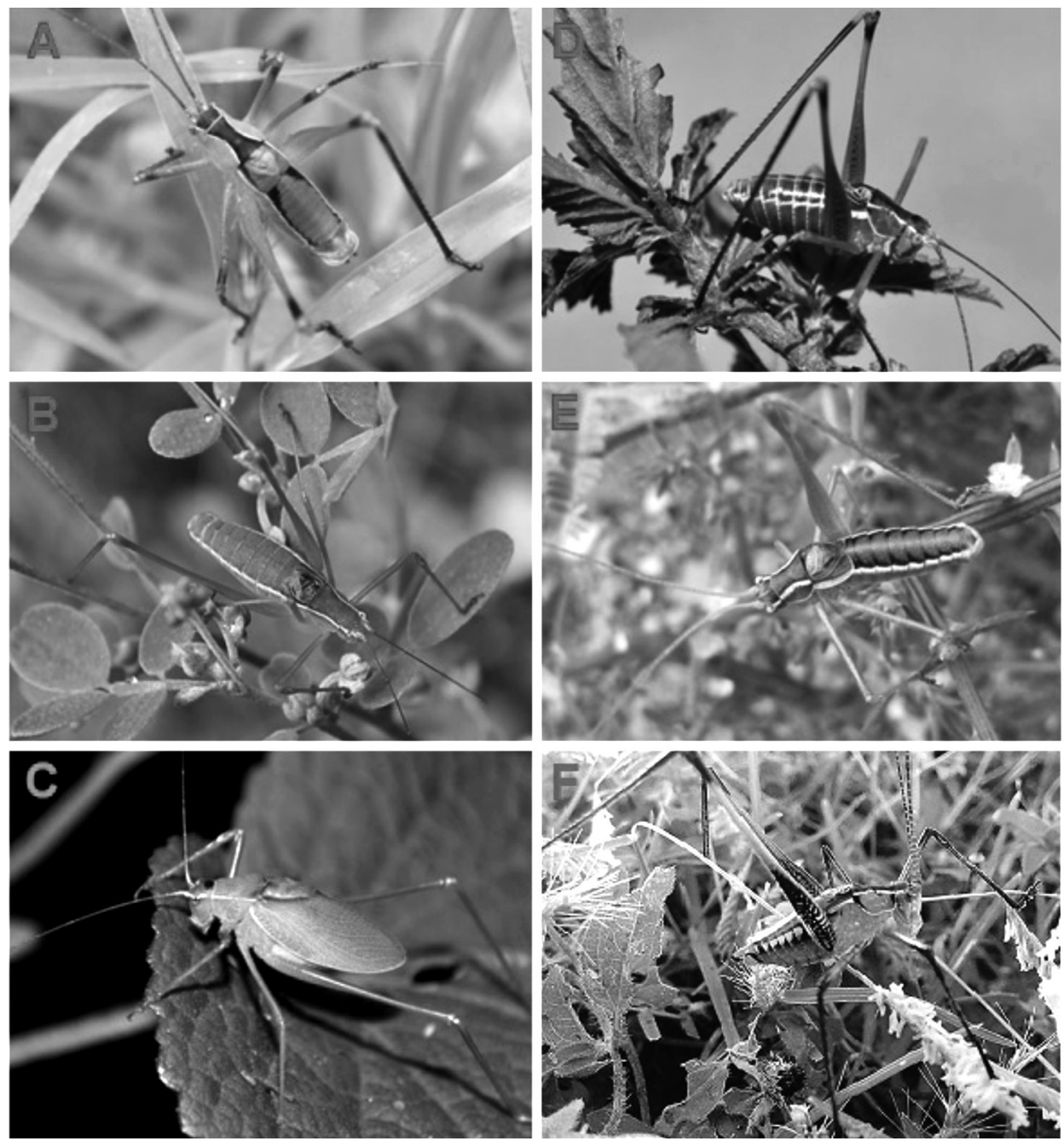

Fig. 3. Genera of the Dichopetala group. A. Acanthorintes zeuglaius Cohn, Swanson \& Fontana, 2014. B. Planipollex pollicifer (Rehn \& Hebard, 1914). C. Pterodichopetala tuliensis Barrientos-Lozano \& Rocha-Sánchez, 2015. D. Obolopteryx castanea (Rehn \& Hebard, 1914). E. Rhabdocerca caudelli (Rehn \& Hebard, 1914). F. Mactruchus serrifer (Rehn \& Hebard, 1914).

separate species based on both their morphological features (Fig. 8) and sequence based tree topologies (Acanthorintes spp. 5, 2, 1, 6, $4,7,3)$. The followings relationships are well supported (CONC60 matrix): A. sp. 5, San Luis Potosí; A. sp. 1, Guanajuato; A. sp. 7, Querétaro ( $\mathrm{PP}=1$, BTP $=30-84)$. The Bayesian and ML phylogram (CONC94 matrix), recovered Acanthorintes spp. 5, 2, 1, as closely related to A. zeuglaius $(\mathrm{PP}=0.89, \mathrm{BTP}=52$ ). Acanthorintes sp. 4 was recuperated as sister to
A. sp. $6(\mathrm{PP}=0.91, \mathrm{BTP}=60)$ and $A$. sp. 3 as sister to Acanthorintes sp. $7(\mathrm{PP}=0.65$, BTP = 38). In all phylograms Acanthorintes was closely related to the Pterodichopetala clade (CONC60: $\mathrm{PP}=1, \mathrm{BTP}=85 ;$ CONC94: $\mathrm{PP}$ $=67, \mathrm{BTP}=19)$. Regarding the Phaneropterinae clade Insara, Scudderia, Microcentrum, and Amblycorypha were recovered as monophyletic in all phylograms ( $\mathrm{PP} \geq 0.92$; $\mathrm{BTP}=$ 40-97), with Insara as sister to the remaining Phaneropterinae genera $(\mathrm{PP} \geq 0.93 ; \mathrm{BTP} \geq 45)$. 

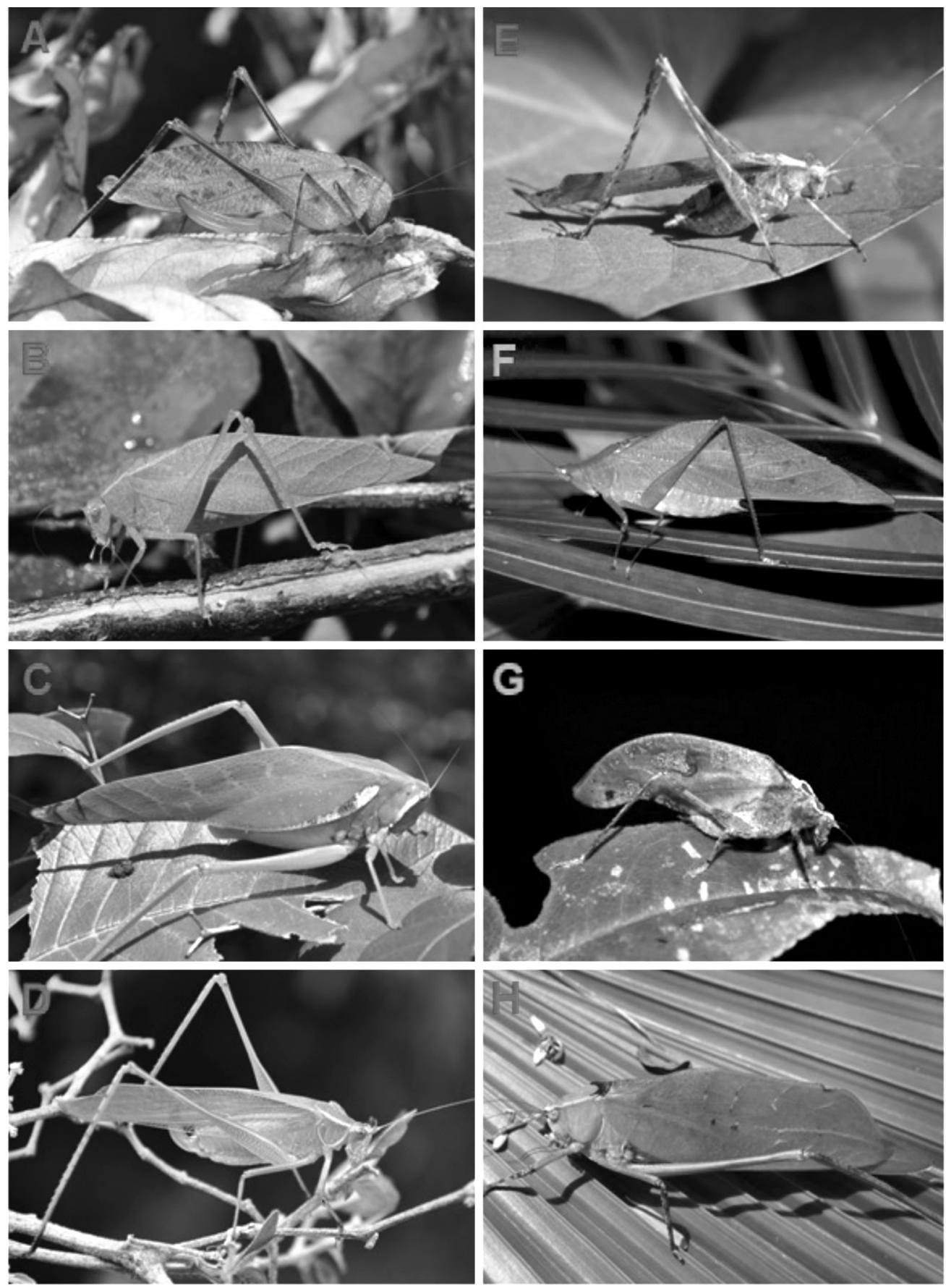

Fig. 4. Other Phaneropterinae genera included in the analyses. A. Amblycorypha huasteca (Saussure, 1859). B. Microcentrum rhombifolium (Saussure, 1859). C. Philophyllia guttulata Stål, 1873. D. Scudderia furcata furcata Brunner von Wattenwyl, 1878. E. Insara tolteca (Saussure, 1859). F. Petaloptera zendala (Saussure, 1859). G. Pycnopalpa (Pycnopalpa) bicordata (Saint-Fargeauy Serville, 1825). H. Stilpnochlora thoracica (Serville, 1831). 

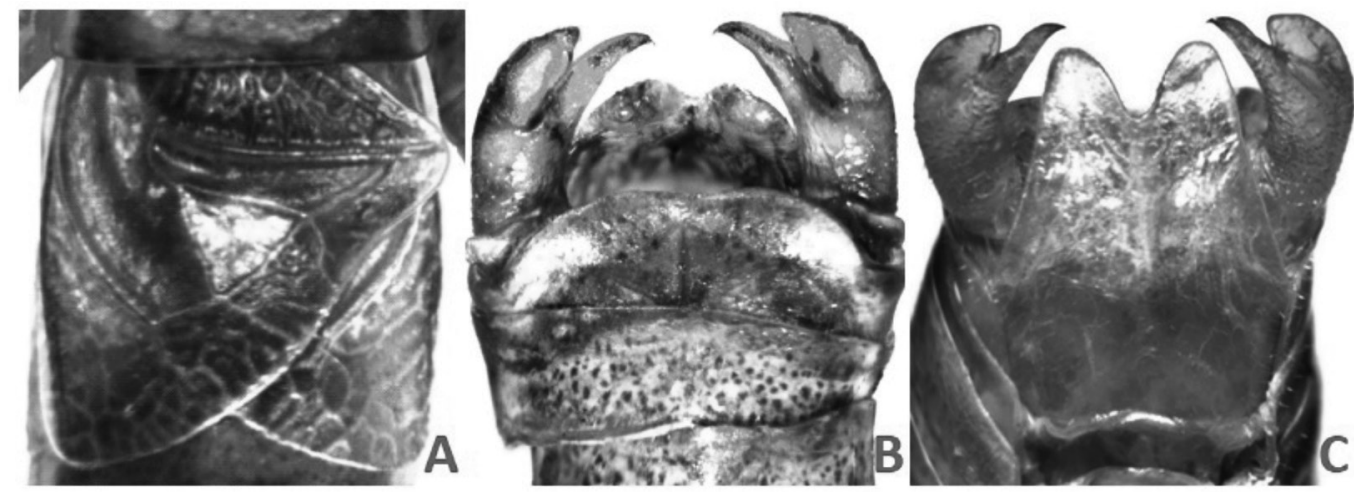

Fig. 5. Planipollex pollicifer male. A. stridulatory area; B. cerci and terminal tergite, dorsal view; C. cerci and subgenital plate, ventral view.
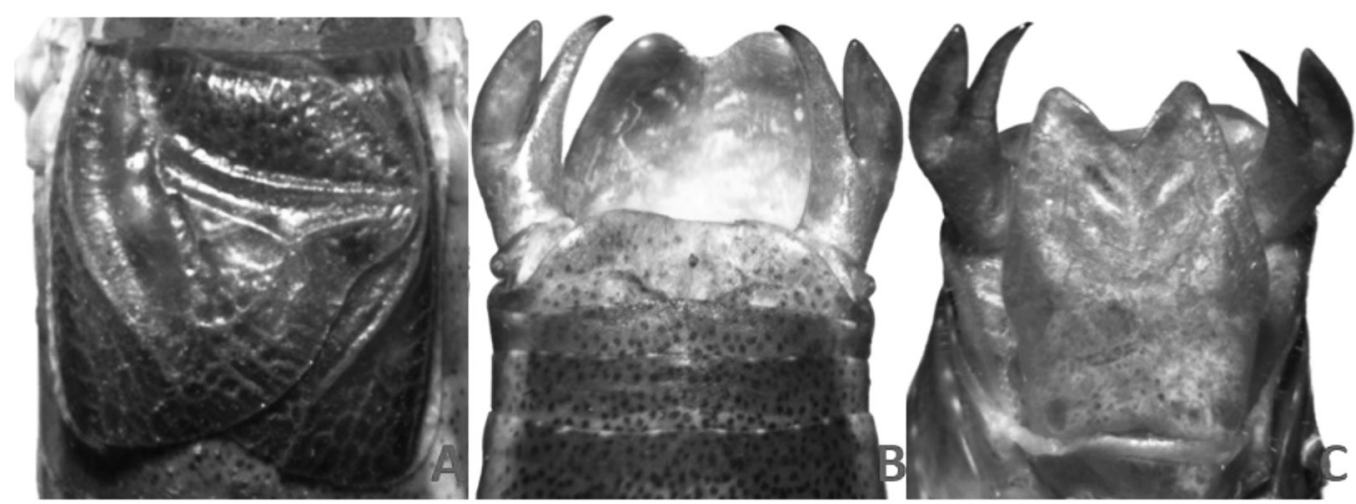

Fig. 6. Planipollex chirura male. A. stridulatory area; B. cerci and terminal tergite, dorsal view; C. cerci and subgenital plate, ventral view.

Amblycorypha and Stilpnochlora were also recovered as sister taxa $(\mathrm{PP} \geq 0.99$; $\mathrm{BTP} \geq 51)$.

\section{DISCUSSION}

This work represents the first contribution on the phylogeny of the Dichopetala group members. Our phylogenetic analyses confirmed the monophyly of this genus group with respect to the rest of the Phaneropterinae taxa included in the analyses and support its generic classification as proposed by Cohn et al. (2014). These authors also consider that the Dichopetala group may represent an independent tribe from the rest of the tribe Odonturini. Although, in this study we did not include other taxa of the Odonturini, our results herein obtained on the monophyly of the Dichopetala group suggest its separation from other Odonturini as proposed by Cohn et al. (2014) based on a single morphological feature, the females' subgenital plate. This feature is divided into two separated sclerotized lobes by a medial-longitudinal membrane. According to Cohn et al. (2014), this character is shared by all genera of the Dichopetala group and none of other Phaneropterinae studied possesses it. They also consider that the females' subgenital plate represents an apomorphic character since it is unique to members of the Dichopetala group. Accordingly, other genera of Odonturini possess a simple triangular female subgenital 


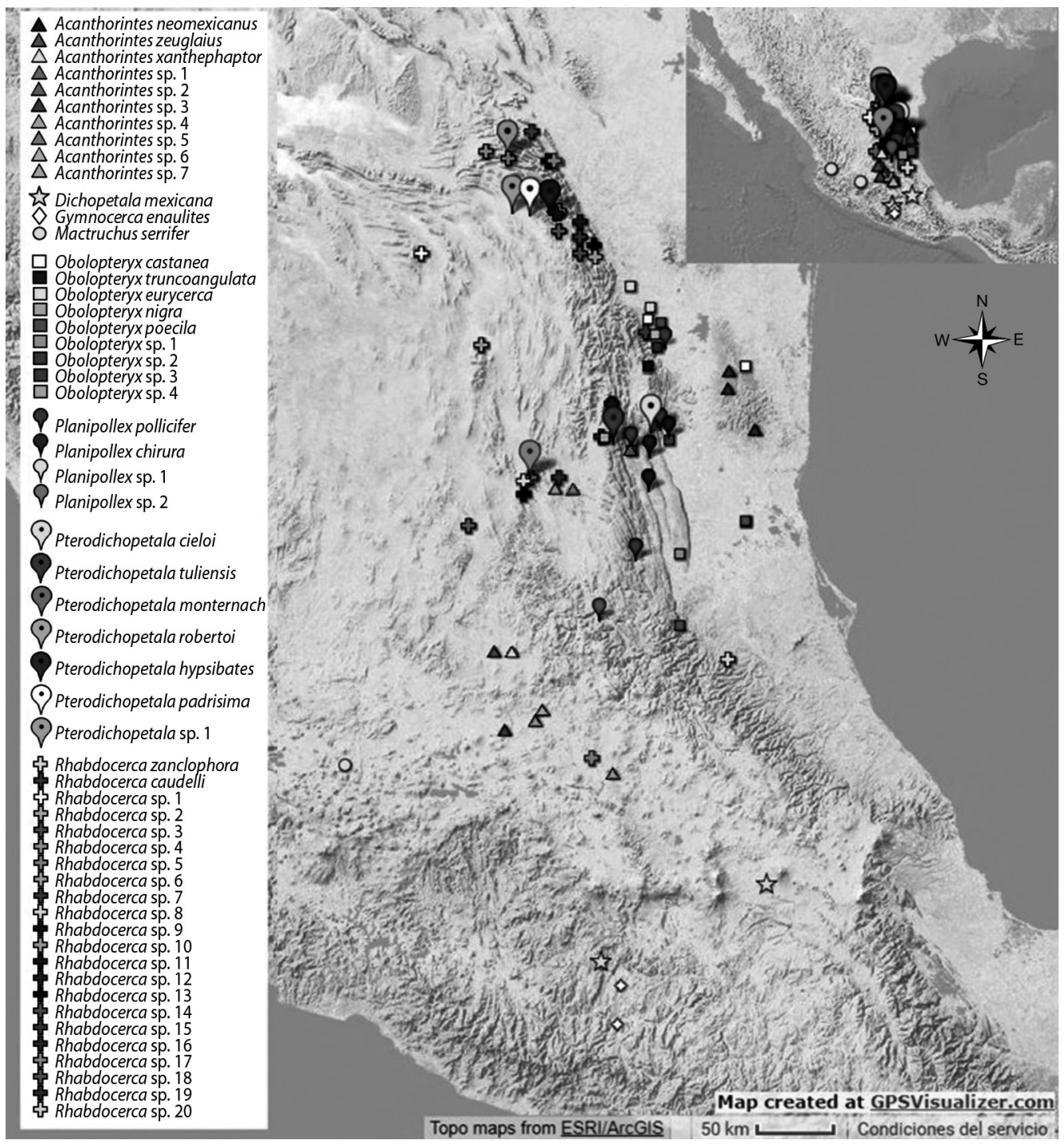

Fig. 7. Geographic distribution of the Dichopetala group members.

plate completely sclerotized, considering this as a primitive condition. Therefore, further phylogenetic studies considering additional taxa of Odonturini may be necessary to confirm whether the Dichopetala group could be raised to a tribe category.

The results obtained in our phylogenetic analyses are congruent with the taxa delimitation based on morphological traits, i.e., males' genitalic characters (cerci, epiproct, subgenital plate, internal genitalia) are useful to separate genera and species of the Dichopetala group. This also agrees with Cohn et al. (2014) and Kensinger et al. (2017) studies, the latter being a molecular study on the genus Obolopteryx which found that morphological characteristics such as the shape of cerci are a diagnostic character that serves for delimitation of that genus of the Dichopetala group. Several authors have demonstrated that male and female genitalic characters, external and internal, are subject to intense sexual selection pressure 

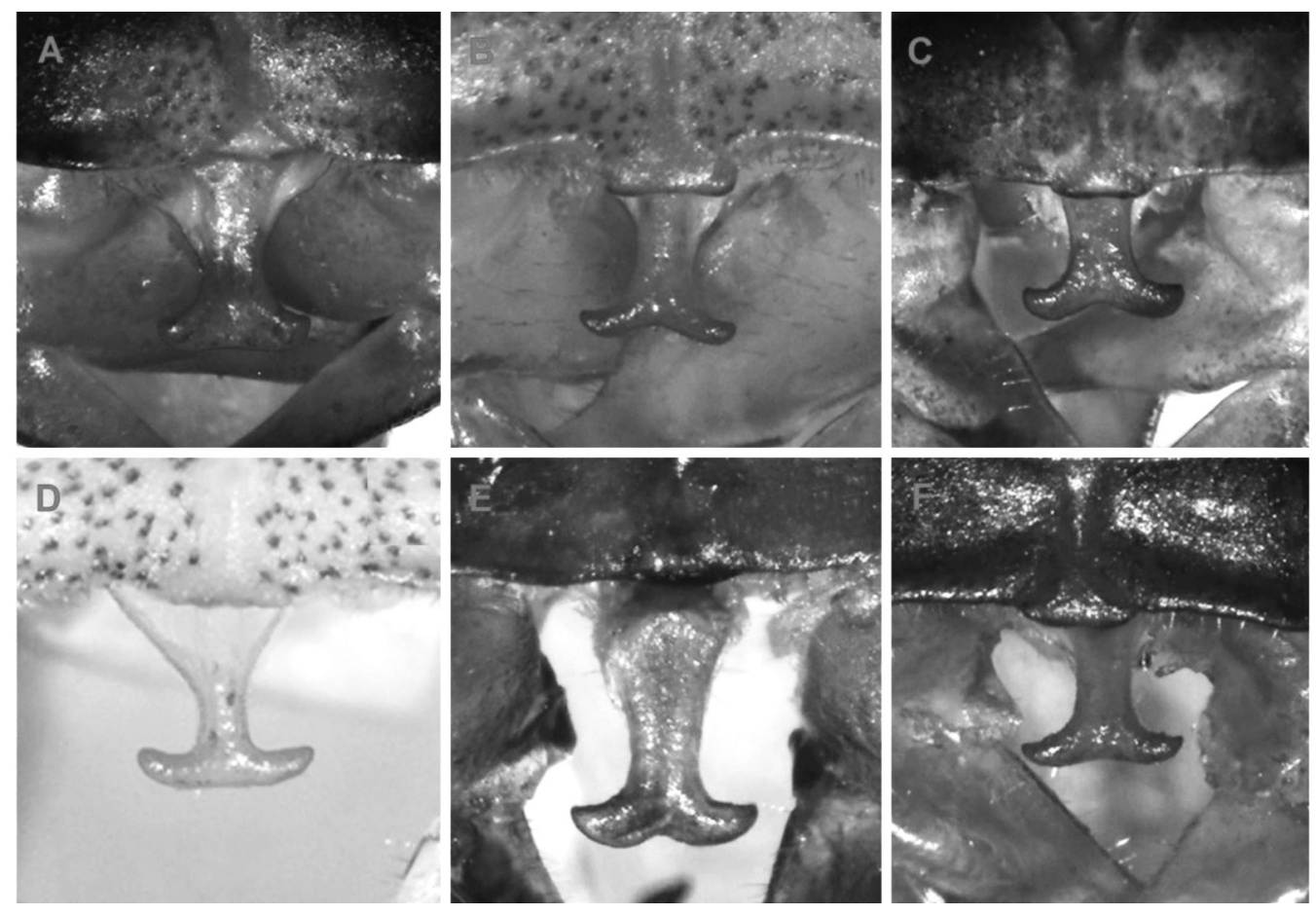

Fig. 8. Acanthorintes males' epiproct variation, frontal view. A. Acanthorintes sp. 1; B. Acanthorintes sp. 2; C. Acanthorintes sp. 4; D. Acanthorintes sp. 5; E. Acanthorintes sp. 6; F. Acanthorintes sp. 7.

and evolve more rapidly than other morphological traits, and thus they vary at specific, generic and suprageneric levels (Eberhard, 2004; Chamorro-Rengifo \& Lopes-Andrade, 2014). Regarding the generic relationships, the rearrangement proposed by Cohn et al. (2014) for the genus Dichopetala sensu latu into six additional genera was mostly supported by our phylogenetic analyses, with Dichopetala, Obolopteryx, Planipollex, Mactruchus and Rhabdocerca confirmed as monophyletic.

The placement of the species that were reassigned to the new genera erected by Cohn et al. (2014) [O. castanea (Rehn \& Hebard, 1914), O. poecila (Hebard, 1932), P. pollicifer (Rehn \& Hebard, 1914), R. caudelli (Rehn \& Hebard, 1914), M. serrifer (Rehn \& Hebard, 1914) and A. neomexicanus (Barrientos-Lozano \& Ramírez-Núñez, 2013)] is also supported in our study. The grouping obtained in our phylograms agrees with the classification reported by Cohn et al. (2014) based on morphological features. Pterodichopetala was recovered in our analyses as the basal lineage of the Dichopetala group, followed by Acanthorintes. Cohn et al. (2014) pointed out that Acanthorintes is morphologically similar to Pterodichopetala due to their similarity in the last abdominal tergite, which has two acute projections of medium size. This feature is only present in members of these two genera within the Dichopetala group and possibly represents a symplesiomorphy for these two genera. Members of Pterodichopetala also have other distinctive morphological features not present in the remaining genera of the Dichopetala group, such as tegmina and pronotum with different shape and size and more complex external and internal male genitalia (Cohn et al., 2014; Rocha-Sánchez et al., 2015; Barrientos-Lozano et al., 2015, 2016).

Phylogenetic relationships among species of Pterodichopetala in the CONC94 Bayesian phylogram are concordant with the results of Cohn et al. (2014) based on morphology. 
Accordingly, morphological features of male genitalia are taxonomically informative to delimit this genus and its members. Pterodichopetala tuliensis and $P$. monternach are in the most basal sub-clade, with these two species having cerci with two branches (Buzzetti et al., 2010; Barrientos-Lozano \& Rocha-Sánchez, 2013; Barrientos-Lozano et al., 2013b; RochaSánchez et al., 2015). Pterodichopetala robertoi, P. padrisima and P. sp. 1 on the other hand are grouped in an additional sub-clade, and are morphologically characterized by having cerci with three branches (Buzzetti et al., 2010; Barrientos-Lozano \& Rocha-Sánchez, 2013; Barrientos-Lozano et al., 2013b; RochaSánchez et al., 2015). Therefore, taking into account this molecular and morphological evidence, we suggest splitting Pterodichopetala into two genera.

All specimens assigned to Obolopteryx based on morphological characters were grouped into a single clade in our molecular analyses. This result agrees with Kensinger et al. (2017), who performed a molecular phylogenetic study for this genus considering seven species (O. emarginata, O. brevihastata, $O$. gladiator, O. seeversi, O. catinata, O. castanea and $O$. oreoeca). These authors recovered this genus as monophyletic. Our phylograms show $O$. nigra closely related to $O$. castanea, which agrees with Barrientos-Lozano et al. (2016) taxonomic study. They pointed out that these two species are morphologically similar, though they differ in cerci, subgenital plate of males and females, epiproct, stridulatory file, acoustic signal and internal genitalia (titillators). Obolopteryx eurycerca appears as the most basal lineage within the genus clade, followed above by $O$. truncoangulata. Barrientos-Lozano et al. (2016) considered O. eurycerca morphologically similar to $O$. castanea, but this relationship is not sustained in this study.

Cohn et al. (2014) synonymized $P$. chirura with $P$. pollicifer, since they did not find consistent morphological features in the topotypic material of $P$. pollicifer from Brownsville, Texas, and specimens of $P$. chirura from Ciudad Valles, San Luis Potosí, Mexico. However,
Strohecker (1945) had mentioned previously that there are differences between males' cerci of P. pollicifer and P. chirura. Cohn et al. (2014) regarded cerci differences between males of these two taxa "as minor", and difference in length of the ovipositor between females "as not a constant character". We included sequences of four populations of this genus in our study that were collected at different localities. In one of our Bayesian phylograms (CONC94 matrix), this genus was divided into two subclades, with a sub-clade containing $P$. chirura (Antiguo Morelos, Tamaulipas) and $P$. sp. 2 (Naranjos Amatlán, Veracruz), and the other $P$. pollicifer (Gómez Farías, Tamaulipas) and $P$. sp. 1 (Huejutla de Reyes, Hidalgo). Accordingly, $P$. pollicifer and $P$. chirura, although morphologically similar, actually may represent distinct species. Therefore, it is proposed to reestablish the specific status of $P$. chirura. Males of these two taxa may be separated by morphological features such as the cerci, subgenital plate, pronotum, and stridulatory file (Fig. 5, Fig. 6) (Barrientos-Lozano et al., in prep.).

Some widely distributed species of the Dichopetala group may represent species complexes. This may be the case of genera Rhabdocerca and Acanthorintes, included in this study. The genus Rhabdocerca currently contains three species $(R$. caudelli, $R$. tridactyla and $R$. zanclophora) that are distributed along central and Northern Mexico (Cohn et al., 2014; Cigliano et al., 2018). In the CONC60 Bayesian phylogram, out of 20 morphospecies assigned to Rhabdocerca 14 were grouped into three main clades whose relationship is consistent with their geographic distribution and their specific status assignment. Each of these clades is distributed along the Mexican Plateau, Mexican Altiplano and Eastern SMO, and Northern most portion of the SMO. Our molecular results support morphological differences, accordingly these populations may be considered as different taxa (Barrientos-Lozano et al., in prep).

We examined sequences of seven morphospecies assigned to the genus Acanthorintes collected in various localities. Males exhibited 
morphological variation in the epiproct (Fig. 8). Acanthorintes spp. 2 and 5 (Fig. 8), which were collected in San Luis Potosí, are characterized by having a slimmer epiproct. On the other hand, in specimens from locations further South the epiproct is more robust (Acanthorintes spp. 1 and 3, from Guanajuato; Acanthorintes spp., 4 and 7, from Querétaro; Acanthorintes sp. 6, Estado de México) (Fig. 8). All phylograms recovered a clade that may contain various independent evolutionary lineages based on $\mathrm{COI}+\mathrm{H} 3+28 \mathrm{~S}$ tree topologies. Cohn et al. (2014) recognized five species for Acanthorintes and pointed out considerable variation in epiproct's projection. Members of Acanthorintes show variation not only in epiproct's projection, but also in other diagnostic morphological characters such as cerci, subgenital plate, stridulatory file and internal genitalia (titillators) (Barrientos-Lozano et al., in prep.). Our results suggest an overlooked species diversification in this genus, which could be explained by its wide geographic distribution in central and Northeastern Mexico. A rapid evolution of genital structures in Acanthorintes, driven by sexual selection mechanisms and ecological factors (biotic and abiotic), probably acted as an effective mean of reproductive isolation (Eberhard, 2004; Hosken \& Stockley, 2004; Rowe \& Arnqvist, 2012; Masly, 2012; Barrientos-Lozano et al.. 2013a; Simmons, 2014).

In the Bayesian phylogram derived from the CONC94 matrix, sequences of specimens assigned to A. neomexicanus and Gymnocerca enaulites exhibited an incongruent arrangement. A similar situation occurred for Gymnocerca enaulites and Planipollex sp. 1 in the Bayesian phylogram derived from the CONC60 matrix. These incongruences may be artifacts caused by the high amount of missing data in their sequence.

Ethical statement: authors declare that they all agree with this publication and made significant contributions; that there is no conflict of interest of any kind; and that we followed all pertinent ethical and legal procedures and requirements. All financial sources are fully and clearly stated in the acknowledgements section. A signed document has been filed in the journal archives.

\section{ACKNOWLEDGMENTS}

We acknowledge field work support provided by the Tecnológico Nacional de MéxicoInstituto Tecnológico de Cd. Victoria. The Consejo Nacional de Ciencia y Tecnología (CONACYT-México) granted financial support to AYRS (Doctoral scholarship No. 262422). Funds were also available from CONACYT to accomplish this work through the project CB-2013-01-0219979. This work was also partially funded by a grant provided to AZR by the UNAM (PAPIIT-DGAPA), convocatoria 2019, Proyecto No. IN201119.

\section{RESUMEN}

Sistemática molecular del grupo de géneros Dichopelata (Orthoptera: Phaneropteridae). Introducción: El grupo de géneros Dichopetala se propuso recientemente después de una revisión del género Dichopetala Brunner von Wattenwyl, 1878. Actualmente, el grupo consta de ocho géneros y 44 especies distribuidas desde el sur de los Estados Unidos hasta el sur de México. Este acuerdo genérico, se basó únicamente en evidencia morfológica y se acompañó por discusiones sobre nuevos géneros erigidos, para los cuales no se probó su monofilia. Objetivo: Evaluar las relaciones filogenéticas entre especies representativas de los ocho géneros del grupo Dichopetala. Métodos: Generamos secuencias de ADN para un gen mitocondrial (Citocromo oxidasa I: COI) y dos marcadores de genes nucleares (28S, Histona III: H3), e incluimos especies de otros géneros de Phaneropterinae para probar la monofilia del grupo en estudio. Utilizamos modelos evolutivos bayesianos y de máxima verosimilitud. Resultados: Se respalda la monofilia del grupo Dichopetala y la monofilia de los géneros Dichopetala, Obolopteryx, Planipollex, Mactruchus y Rhabdocerca. Además, los géneros Acanthorintes y Pterodichopetala como parafiléticos. Los marcadores mitocondriales también sugieren que los géneros Rhabdocerca y Acanthorintes ampliamente distribuidos, pueden en realidad contener varias especies no vistas previamente. Conclusión: Se proporciona la primera contribución a la filogenia del grupo de Dichopetala y una definición filogenética y morfológica más robusta de algunos de los géneros involucrados. 
Palabras clave: Dichopetaline, análisis molecular, monofilia, morfología.

\section{REFERENCES}

Arce-Pérez, R., \& Morón, M. A. (2000). Taxonomía y distribución de las especies de Macrodactylus latreille (Coleoptera: Melolonthidae) en Mexico y Estados Unidos de America. Acta Zoológica Mexicana, 79, 123-239.

Barrientos-Lozano, L. (2004). Orthoptera. In J. E. Llorente-Bousquets, J. J. Morrone, O. Yáñez-Ordoñez, \& I. Vargas-Fernández (Eds.), Biodiversidad, taxonomía y biogeografía de artrópodos de México: hacia una sintesis de su conocimiento (pp. 608-625). México: Universidad Nacional Autónoma de México.

Barrientos-Lozano, L., \& Rocha-Sánchez, A. Y. (2013). A new species of the genus Pterodichopetala (Orthoptera: Tettigoniidae: Phaneropterinae) from northeastern Mexico. Journal of Orthoptera Research, 22(1), $3-13$.

Barrientos-Lozano, L., Ramírez-Núñez, J. B., RochaSánchez, A. Y., Horta-Vega, J. V., \& Almaguer-Sierra, P. (2013a). Contribución al conocimiento de la fauna Orthoptera (Insecta) en la "Sierra de Tamaulipas", México. TecnoINTELECTO, 10(1), 32-42.

Barrientos-Lozano, L., Rocha-Sánchez, A. Y., Buzzetti, F. M., Méndez-Gómez, B. R., \& Horta-Vega, J. V. (2013b). Saltamontes y Esperanzas del Noreste de México. Guía Ilustrada. México: Editorial Porrúa.

Barrientos-Lozano, L., Rocha-Sánchez, A. Y., \& CorreaSandoval, A. (2015). A new species of the genus Obolopteryx Cohn et al. 2014 and a conspecific gynandromorph (Ensifera: Tettigoniidae: Phaneropterinae). Zootaxa, 4028(4), 485-510.

Barrientos-Lozano, L., Rocha-Sánchez, A. Y., ZaldívarRiverón, A., \& Correa-Sandoval, A. (2016). Additional new species of the genus Obolopteryx Cohn et al. 2014 (Ensifera: Tettigoniidae) from Northeastern Mexico. Zootaxa, 4168(3), 401-452.

Belshaw, R., \& Quicke, D. L. J. (1997). A molecular phylogeny of the Aphidiinae (Hymenoptera: Braconidae) Molecular Phylogenetics and Evolution, 7, 281-293.

Brunner von Wattenwyl, K. (1878). Monographie der Phaneropteriden. Viena, Austria: F.A. Brockhaus.

Burmeister, H. (1838). Kaukerfe, Gymnognatha (Erste Hälfte: Vulgo Orthoptera). Handbuch der Entomologie, 2(2), 397-756.

Buzzetti, F. M., Barrientos-Lozano, L., \& Rocha-Sánchez, A. Y. (2010). Description and bioacoustics of a new species of the new genus Pterodichopetala from Mexico (Insecta: Orthoptera: Tettigoniidae:
Phaneropterinae). Journal of Orthoptera Research, 19(2), 289-292.

Cigliano, M. M., Braun, H., Eades, D. C., \& Otte, D. (2018). Orthoptera Species File Online (Data base). Retrieved from http://Orthoptera.SpeciesFile.org

Chamorro-Rengifo, J., \& Lopes-Andrade, C. (2014). The phallus in Tettigoniidae (Insecta: Orthoptera: Ensifera): revision of morphology and terminology, and discussion on its taxonomic importance and evolution. Zootaxa, 3815, 151-199.

Cohn, T. J., Swanson, D. R., \& Fontana, P. (2014). Dichopetala and New Related North American Genera: A Study in Genitalic Similarity in Sympatry and Genitalic Differences in Allopatry (Tettigoniidae: Phaneropterinae: Odonturini). Michigan, USA: Miscellaneous Publications University of Michigan.

Colgan, D. J., McLauchlan, A., Wilson, G. D. F., Livingston, S. P., Edgecombe, G. D., Macaranas, J., \& Gray, M. R. (1998). Histone H3 and U2 snRNA DNA sequences and arthropod molecular evolution. Australian Journal of Zoology, 46, 419-437.

De Jesús-Bonilla, V. S., Barrientos-Lozano, L., \& ZaldívarRiverón, A. (2017). Sequence based species delineation and molecular phylogenetics of the transitional Nearctic-Neotropical grasshopper genus Taeniopoda (Orthoptera, Romaleidae). Systematics and Biodiversity, 15, 600-617.

Eberhard, W. G. (2004). Rapid divergent evolution of sexual morphology: comparative tests of antagonistic coevolution and traditional female choice. Evolution, 58(9), 1947-1970.

Folmer, O., Black, M., Hoeh, W., Lutz, R., \& Vrijenhoek, R. (1994). DNA primers for amplification of mitochondrial Cytochrome c oxidase subunit I from diverse metazoan invertebrates. Molecular Marine Biology and Biotechnology, 3, 294-299.

Fontana, P., Buzzetti, F. M., \& Mariño-Pérez, R. (2008). Chapulines, Langostas, Grillos y Esperanzas de México. Mexico: WBA Handbooks.

Grzywacz, B., Lehmann, A. W., Chobanov, D. P., \& Lehmann, G. U. C. (2018). Multiple origin of flightlessness in Phaneropterinae bushcrickets and redefinition of the tribus Odonturini (Orthoptera: Tettigonioidea: Phaneropteridae). Organisms Diversity and Evolution, 18(3), 327-339.

Heller, K. G., Ingrisch, S., Liu, C. X., Shi, F. M., Hemp, C., Warchałowska-Śliwa, E., \& Rentz, D. C. (2017). Complex songs and cryptic ethospecies: the case of the Ducetia japonica group (Orthoptera: Tettigonioidea: Phaneropteridae: Phaneropterinae). Zoological Journal of the Linnean Society, 181(2), 286-307.

Hillis, D. M., \& Bull, J. J. (1993). An empirical test of bootstrapping as a method for assessing confidence 
in phylogenetic analysis. Systematic Biology, 42(2), 182-192.

Hosken, D. J., \& Stockley, P. (2004). Sexual selection and genital evolution. Trends in Ecology \& Evolution, 19, 87-93.

Kensinger, B. J., Schwemm, M. R., \& Luttberg, B. (2017). Molecular Phylogeny for the Obolopteryx Katydids of the Southwestern United States (Orthoptera: Tettigoniidae: Phaneropterinae). Journal of the Entomological Research Society, 19(3), 7-14.

Lanfear, R., Calcott, B., Ho, S. Y. W., \& Guindon, S. (2012). PartitionFinder: Combined Selection of Partitioning Schemes and Substitution Models for Phylogenetic Analyses. Molecular Biology and Evolution, 29(6), 1695-1701.

Maddison, W. P., \& Maddison, D. R. (2011). Mesquite: a modular system for evolutionary analysis (Software, Version 2.75). Retrieved from https:/www.mesquiteproject.org

Masly, J. P. (2012). 170 Years of "Lock-and-Key": Genital Morphology and Reproductive Isolation. International Journal of Evolutionary Biology, 2012, 1-10.

Mugleston, J. D., Naegle, M., Song, H., Bybee, S. M., Ingley, S., Suvorov, A., \& Whiting, M. F. (2016). Reinventing the leaf: multiple origins of leaf-like wings in katydids (Orthoptera: Tettigoniidae). Invertebrate Systematics, 30(4), 335-352.

Mugleston, J. D., Song, H., \& Whiting, M. F. (2013). A century of paraphyly: A molecular phylogeny of katydids (Orthoptera: Tettigoniidae) supports multiple origins of leaf-like wings. Molecular Phylogenetics and Evolution, 69, 1120-1134.

Rehn, J. A., \& Hebard, M. (1914). A study of the species of the genus Dichopetala (Orthoptera: Tettigoniidae). Proceedings of the Academy of Natural Sciences of Philadelphia, 66, 64-160.

Rocha-Sánchez, A. Y., Barrientos-Lozano, L., \& Zaldívar-Riverón, A. (2015). Additional new species of the genus Pterodichopetala (Phaneropteridae: Phaneropterinae) from Northeastern Mexico. Zootaxa, 3956(3), 301-344.

Rocha-Sánchez, A. Y., Barrientos-Lozano, L., ZaldívarRiverón, A., \& Almaguer-Sierra, P. (2016). Importancia de la genitalia en la delimitación de especies de la subfamilia Phaneropterinae (Orthoptera: Tettigoniidae). Entomología Mexicana, 3, 943-949.

Ronquist, F., \& Huelsenbeck, J. P. (2003). MrBayes 3: Bayesian phylogenetic inference undermixed models. Bioinformatics, 19, 1572-1574.
Rowe, L., \& Arnqvist, G. (2012). Sexual selection and the evolution of genital shape and complexity in water striders. Evolution, 66(1), 40-54.

Sanabria-Urbán, S., Song, H., Oyama, K., GonzálezRodríguez, A., \& Cueva Del Castillo, R. (2017). Integrative taxonomy reveals cryptic diversity in Neotropical grasshoppers: taxonomy, phylogenetics, and evolution of the genus Sphenarium Charpentier, 1842 (Orthoptera: Pyrgomorphidae). Zootaxa, 4274(1), 1-86.

Genecodes Corporation. (2011). Sequencer version 4.1.4 (Software). Retrieved from http://www.genecodes. com

Simmons, L. W. (2014). Sexual selection and genital evolution. Austral Entomology, 53(1), 1-17.

Song, H. (2015). 300 million years of diversification: elucidating the patterns of orthopteran evolution based on comprehensive taxon and gene sampling. Cladistics, 31(6), 1-31.

Stamatakis, A. (2014). RAxML version 8: a tool for phylogenetic analysis and post-analysis of large phylogenies. Bioinformatics, 30, 1312-1313.

Strohecker, H. F. (1945). Notes on and descriptions of Mexican Orthoptera. Annals of the Entomological Society of America, 38(2), 207-215.

Svenson, G. J., \& Whiting, M. F. (2004). Phylogeny of Mantodea based on molecular data: evolution of a charismatic predator. Systematic Entomology, 29(3), 359-370.

Swofford, D. L. (2002). PAUP* (*Phylogenetic Analysis Using Parsimony) (Software, Version 4). Sinauer Associates. Sunderland, Massachusetts. Retrieved from http://phylosolutions.com/paup-test

Walker, T. J., Forrest, T. G., \& Spooner, J. D. (2003). The rotundifolia complex of the genus Amblycorypha (Orthoptera: Tettigoniidae): songs reveal new species. Annals of the Entomological Society of America, 96(4), 433-447.

Whiting, M. F. (2002). Mecoptera is paraphyletic: multiple genes and phylogeny of Mecoptera and Siphonaptera. Zoologica Scripta, 31, 93-104.

Zaldívar-Riverón, A., Mori, M., \& Quicke, D. L. J. (2006). Systematics of the cyclostome subfamilies of braconid parasitic wasps (Hymenoptera: Ichneumonoidea): A simultaneous molecular and morphological Bayesian approach. Molecular Phylogenetics and Evolution, 38, 130-145. 